\title{
Comparison of physical fitness in elderly submitted to different physical exercise interventions
}

\section{Comparação da aptidão física em idosos submetidos a diferentes intervenções de exercício físico}

Leonardo de Campos', Priscila Missaki Nakamura",2, Eduardo Kokubun

\begin{abstract}
The objective was to investigate the influence of two types of physical exercise intervention on elderly individuals' physical fitness. The study included 17 older adults with a mean age of 65.8 years $( \pm 2.88)$, divided into two groups: Programa de Exercícios Físicos em Unidades de Saúde (PEFUS - Physical Exercise Program in Health Units, $\mathrm{n}=8$ ) and Adapted Volleyball $(\mathrm{n}=9)$. PEFUS classes were held three times a week and lasted 90 minutes, including strength, aerobic endurance, agility, coordination and balance exercises. Adapted Volleyball classes were performed two times per week and lasted 120 minutes, divided into skill volleyball exercises and game. For the evaluation of physical skills (strength, agility, coordination and flexibility), the American Alliance for Health, Physical Education, Recreation and Dance (AAHPERD) set of tests was performed. All participants were assessed at the baseline and after three months of interventions. Statistical analysis was performed using factorial ANOVA through SPSS, version 17.0, and a significance level $p<0.05$. Motor coordination showed significant improvements after three months of interventions, decreasing from $11.7 \pm 2.3$ to $10.1 \pm 1.6$ seconds for Adapted Volleyball and from $15.8 \pm 3.3$ to $12.0 \pm 3.5$ seconds for PEFUS $(\mathrm{p}<0.05)$. Regarding strength endurance, there was a group-moment interaction $(p<0.05)$ and the PEFUS group showed an increase in this variable after intervention. The interventions are beneficial to the physical fitness of elderly individuals, because they increase or maintain such fitness after these interventions.
\end{abstract}

\section{Keywords}

Aged; Volleyball; Physical Fitness; Exercise; Primary Health Care.

\section{Resumo}

O objetivo foi verificar a influência de dois tipos de intervenções de exercício físico sobre a aptidão física de idosos. Participaram do estudo 17 idosos com média de idade 65,8 anos $( \pm 2,88)$ divididos em dois grupos, Programa de Exercícios Físicos em Unidade de Saúde (PEFUS; $n=8$ ) e Voleibol Adaptado (n=9). As aulas do PEFUS foram realizadas três vezes na semana com duração de 90 minutos englobando exercícios de força, resistência aeróbia, agilidade, coordenação e equilibrio. As aulas do Vôlei Adaptado foram realizadas duas vezes por semana com duração de 120 minutos, dividida em fundamento e jogo. Para avaliação das aptidões físicas foi realizada a bateria de testes da American Alliance for Health, Physical Education, Recreation and Dance (AAHPERD). Todos os participantes foram avaliados no início das intervenções e após três meses. Para análise estatística foi utilizada a ANOVA fatorial através do SPSS versão 17.0 e foi adotado nível de significância $p<0,05$. Após três meses de intervenção a variável coordenação apresentou melhoras significativas para o Voleibol Adaptado diminuindo de $11,7 \pm 2,3$ para $10,1 \pm 1,6$ segundos e para PEFUS de $15,8 \pm 3,3$

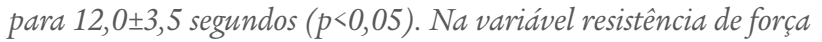
foi verificada uma interação entre grupo e momento ( $p<0,05)$, na qual o grupo PEFUS melhorou essa capacidade após a intervenção. As intervenções foram benéficas a aptidão física de idosos devido ao aumento ou manutenção dos componentes da aptidão física após intervenção.

\section{Palavras-chave}

Idoso; Voleibol; Aptidão física; Exercício; Atenção primária à saúde

\section{Introduction}

1- UNESP, Biosciences Institute, Postgraduate Program of Kinetic Sciences, Rio Claro, São Paulo, Brazil.

2- IFSULDEMINAS, Department of Physical Education, Muzambinho, Minas Gerais, Brazil.
It is estimated that the world population aged more than 60 years will double from $11 \%$ to $22 \%$ between 2000 and 2050. It will take less than 25 years for the number of individuals aged more than 65 years to double in countries such as Brazil and China. By 
2025 , Brazil will have more than $12.5 \%$ of its population over the age of 60 years ${ }^{1}$.

The Brazilian elderly population has increased the top of the age pyramid in the last decade. The last census conducted in 2010 showed that individuals aged more than 65 years totaled $7.4 \%$ of the population ${ }^{2}$.

Aging promotes cardiovascular and musculoskeletal changes in an organism ${ }^{3}$. Among the harmful effects of the aging process that stand out are the loss of skeletal muscle mass and strength (sarcopenia), motor coordination, flexibility and aerobic capacity ${ }^{4}$. The effects of aging combined with physical inactivity increase the risk of institutionalization and development of diseases ${ }^{3}$ and decrease quality of life ${ }^{5}$.

Physical exercise can prevent, treat and delay the development of diseases associated with lifestyle. An active lifestyle enables improvements in physical fitness and decrease in the prevalence of diseases ${ }^{6}$. There is an inverse relationship between physical activity level and mortality. Additionally, a change in lifestyle, including physical exercise practice, has a positive impact on health and longevity, especially after the age of 50 years, with an increasing importance for the prevention and control of non-communicable diseases and other health conditions?.

However, a small number of individuals continue to be physically active when they reach the age of 60 years. Approximately $65 \%$ of the elderly population does not have a moderate and/or vigorous physical activity level to meet the global recommendations aimed at obtaining health benefits ${ }^{8}$, thus promoting the development of non-communicable diseases and other health conditions ${ }^{7}$.

In this sense, physical inactivity is a public health problem and the challenge in the $21^{\text {st }}$ century is to enable individuals to become more physically active? Among the innumerable ways to practical physical exercises in old age, adapted volleyball ${ }^{8,10,11}$ and physical exercise interventions ${ }^{12}$ in primary care have been used to improve elderly individuals' fitness. Thus, the present study aimed to observe the influence of these two types of physical exercise interventions on their physical fitness.

\section{Methods}

\section{Population and study design}

Elderly individuals aged $\geq 60$ years of both sexes and without medical restrictions for physical exercise practice (less than three risk factors in the Physical Activity Readiness Questionnaire - PAR-Q) participated in the present study. Participants were selected from Primary Care Units without a physical exercise intervention and among the elderly who practiced adapted volleyball at the Bank Workers' Club in the city of Rio Claro, SP, Brazil. The exclusion criterion was not having one of the evaluations performed.

The sample calculation was performed with the G-Power program, version 3.10, and the following values were used: effect size $f=0.5 ; \alpha=0.05$ and power of 0.8 for ANOVA for repeated measures with a total $\mathrm{N}=12$ (six per group).

- Group 1: Seven men and two women aged $65.1 \pm 3.1$ years participated in the adapted volleyball intervention. These individuals took part in an adapted volleyball program offered by the government of the city of Rio Claro and they had resumed their classes two weeks earlier, after nearly three months of vacation. The teacher was contacted and those who practiced this activity were subsequently invited to participate in the research project and have physical fitness tests performed. Of all 20 participants who had the first evaluation, 12 
were older than 60 years and only nine continued to participate in the classes and had the second evaluation.

- Group 2: Eight women aged $64.3 \pm 4.1$ years participated in the physical exercise intervention at the Primary Care Unit. This group was part of a larger project conducted in Primary Care Units where only the elderly from such intervention were included in the present study. This intervention was at first promoted in locations near the health unit which did not have the Programa de Exercicios Fisicos em Unidades de Saúde (PEFUS - Physical Exercise Program in Health Units), through newspaper advertisements, banners, invitation from the Physical Education professional to those who frequently used the unit and recommendation from other professionals. A total of 140 individuals signed up, 87 had the first evaluation performed, 46 began the program, ten were older than 60 years and eight stayed until the end of the intervention.

All participants who accepted to participate in this research project read and signed an Informed Consent Form approved by the Research Ethics Committee of the university where such project was developed, under number 822 .

\section{Classes}

- Group 1: Adapted Volleyball classes (G1) - Classes were held twice a week and lasted 120 minutes, under the supervision of a Physical Education professional working for the city government. Classes followed the following structure: initial part, technical and tactical part, and main part (game). The main characteristic that distinguishes this type of volleyball from the conventional one is that holding and/or controlling the ball when receiving or passing it is also considered as a hit ${ }^{11}$.

- Group 2: "Physical Exercise Program in Health Units" classes (G2) were held in a Primary Care Unit in the city of Rio Claro, SP, Southeastern Brazil, three times a week and including 90 minutes of general physical exercises with a moderate intensity, supervised by a Physical Education professional ${ }^{13,14}$. The PEFUS intervention was conducted through activities planned according with the periodization principles of physical training, organized into cycles of four weeks that include cardiorespiratory and neuromotor exercises. Classes were divided into: initial part (10 minutes) with stretching exercises; main part (40 minutes) to perform cardiorespiratory and neuromotor activities and the final part (10 minutes) with more relaxing activities ${ }^{14}$. Participants were instructed to keep the intensity at level 13 of the subjective scale of effort ${ }^{12}$.

\section{Specific procedures}

The evaluations of physical fitness and anthropometric characteristics were assessed at the baseline and after three months. Evaluators ( undergraduate physical education students and postgraduate students) were trained and performed laboratory tests to familiarize with them before test application, maintaining the same evaluators and evaluation standards for the pre- and post-intervention moments.

\section{Evaluation of the Physical Fitness Components}

Evaluation of physical fitness was performed through tests recommended by the American Alliance for Health, Physical Education, Recreation and Dance (AAHPERD). This set of tests assesses flexibility, coordination, upper limb strength resistance, agility and dynamic balance ${ }^{15}$. 


\section{Statistical analysis}

Factorial ANOVA with two factors (Moments and Groups) was performed with SPSS, version 17.0, for the statistical analysis, considering a significance level of $\mathrm{p}<0.05$. All results were expressed as means and standard deviations.

\section{Results}

G1 participants showed a higher level of education and greater height when compared to $\mathrm{G} 2$ participants. With regard to the remaining characteristics, there were no group effects as shown in Table 1.

TABLE 1 - Student's t-test for anthropometric characteristics of participants during the pre-intervention moment (elderly individuals from the city of Rio Claro, SP, Brazil, 2013).

\begin{tabular}{lccc}
\hline & $\begin{array}{c}\mathrm{G} 1 \\
(\mathrm{~N}=9)\end{array}$ & $\begin{array}{c}\mathrm{G} 2 \\
(\mathrm{~N}=8)\end{array}$ & $P$ \\
\hline Age (years) & $65.1 \pm 3.1$ & $64.3 \pm 4.1$ & 0.62 \\
\hline Level of education (years) & $12.5 \pm 3.3$ & $3.6 \pm 4.0$ & $0.00^{*}$ \\
\hline Body weight $(\mathrm{kg})$ & $79.6 \pm 11.4$ & $77.5 \pm 11.2$ & 0.70 \\
\hline Height (meters) & $1.65 \pm 0.1$ & $1.55 \pm 0.1$ & $0.01^{*}$ \\
\hline BMl $\left(\mathrm{kg} / \mathrm{m}^{2}\right)$ & $29 . \pm 3.2$ & $32.0 \pm 4.9$ & 0.12 \\
\hline
\end{tabular}

$\mathrm{BMI}$ - Body mass index; * Significant difference of $\mathrm{p}<0.05$ between $\mathrm{G} 1$ and $\mathrm{G} 2$

G1 participants had a better performance in all physical fitness tests when compared to G2. However, there was an interaction between moment and group for strength resistance. G2 participants showed better results of strength resistance after the intervention, although the opposite occurred among G1 participants. Additionally, both G1 and G2 participants showed improvements in the coordination test, decreasing the execution time after three months of intervention (Table 2 and Figure 1).

TABLE 2 - Factorial ANOVA with two factors (Moments and Groups) of physical fitness during the pre- and post-intervention moments for each group, with values expressed as means and standard deviations (elderly individuals from the city of Rio Claro, SP, Brazil, 2013).

\begin{tabular}{lcccc}
\hline & \multicolumn{2}{c}{$\mathrm{G} 1(\mathrm{~N}=9)$} & \multicolumn{2}{c}{$\mathrm{G} 2(\mathrm{~N}=8)$} \\
\hline Physical fitness 81 & Pre & Post & Pre & Post \\
\hline Strength resistance (repetitions)*+ & $32.2 \pm 6.1$ & $30.4 \pm 3.5$ & $20.4 \pm 5.0$ & $26.3 \pm 6.3$ \\
\hline Coordination (seconds) $^{* *}$ & $11.7 \pm 2.3$ & $10.1 \pm 1.6$ & $15.8 \pm 3.3$ & $12.0 \pm 3.5$ \\
\hline Agility (seconds)* $^{*}$ & $16.6 \pm 1.9$ & $16.6 \pm 1.7$ & $23.8 \pm 3.9$ & $22.0 \pm 3.9$ \\
\hline Flexibility (cm) & $63.6 \pm 10.8$ & $65.6 \pm 9.9$ & $52.8 \pm 7.8$ & $53.8 \pm 9.4$ \\
\hline
\end{tabular}

${ }^{*} p<0.05$ - difference between groups; \# $p<0.05$ - statistical difference between the pre- and post -intervention moments; † $p<0.05$ - interaction between moment and group;

\section{Discussion}

The present study aimed to verify the influence of two types of physical exercise interventions on elderly individuals' fitness. The initial hypothesis was that such interventions, regardless of the type of exercise, would be capable of maintaining or increasing elderly individuals' physical fitness level.

The adapted volleyball group (G1) showed better results in the physical capacity tests when compared to the PEFUS group (G2) ( $\mathrm{p}<0.05)$. Moreover, both groups showed significant improvements in the coordination test after interventions and there was an interaction between groups for the upper limb strength re- 

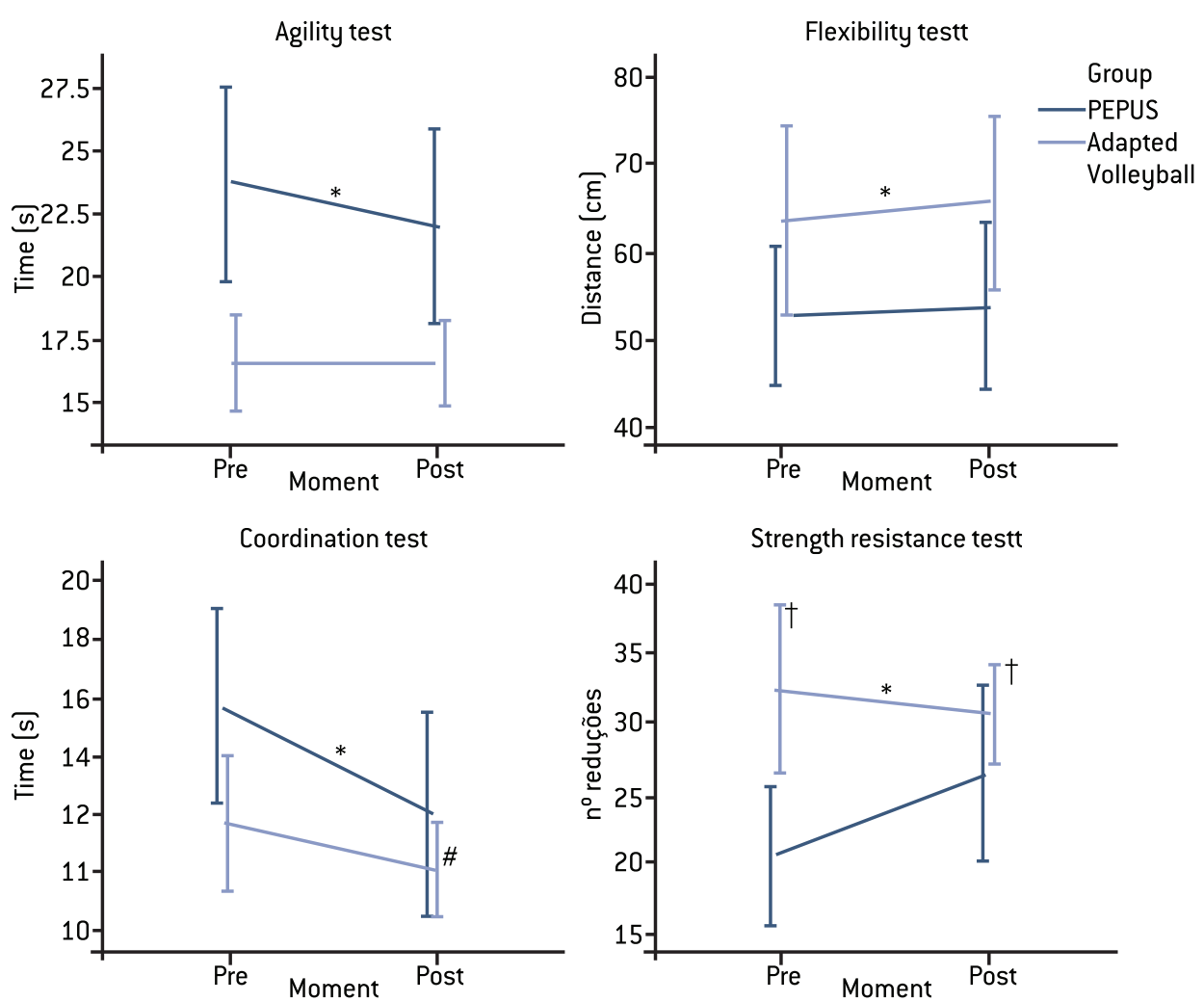

${ }^{*} p<0.05$ - difference between groups; \# $p<0.05$ - statistical difference between the pre- and post -intervention moments; $\uparrow \mathrm{p}<0.05$ - interaction between moment and group.

FIGURE 1 - Results from the physical fitness test (AAHPERD) for the Adapted Volleyball and PEFUS groups during the pre- and post-intervention moments.

sistance test. With regard to the coordination test, groups reduced their execution time: $\mathrm{G} 1$, from $11.7 \pm 2.3$ to $10.1 \pm 1.6$ seconds; and G2, from $15.8 \pm 3.3$ to $12.0 \pm 3.5$ seconds $(\mathrm{p}<0.05)$.

Findings from the present study are in agreement with the results found in the literature, where intervention programs with physical exercise can improve or maintain elderly individuals' physical capacities. These results emphasize the fact that physical exercise practice can improve or maintain elderly individuals' physical capacities. Considering that the aging process itself is harmful to physical fitness, simply maintaining one's fitness levels can already be a benefit for the quality of life of these individuals ${ }^{5,16,17}$.

We could observe that the intervention performed with G2 was effective to improve the tests and that the intervention with G1 was capable of maintaining or improving some physical fitness components. The present study showed that G1 and G2 participants did not have the same initial performance, which can have an influence on the differences in the results obtained from the tests performed between these two groups, mainly in the initial results.

After three months of intervention, G1 and G2 participants showed significant improvements in coordination $(\mathrm{p}<0.05)$. Such improvement through interventions, even with trained elderly individuals, reaffirms the fact that they maintain their trainability and through their physical training they are capable of achieving improvements in their muscular physical capacities ${ }^{6}$. This is also in agreement with findings from Pauli et al. ${ }^{5}$, where, similarly to our study, elderly individuals participating in a physical exercise program with general moderate-intensity activities showed significant improvements after 12 years of practice in a motor coor- 
dination program.

Improvement in the results from the motor coordination test (AAHPERD) may have been influenced by activities of daily living that require a great deal from upper limbs ${ }^{19}$ and they are comprised of oculo-manual coordination activities ${ }^{18}$. Furthermore, improvement in fine motor coordination inherent in sports practice could explain the improvement in motor coordination in $\mathrm{G} 1^{18}$. Another factor that could have influenced such improvement after the intervention is the intraand intermuscular coordination that mainly occurred through training and specificity $^{18}$, especially with G2.

The results of the present study also showed an interaction between moments and groups for upper limb strength resistance. The results shown are not statistically significant to affirm that a group improved or worsened, although an increase of $28.8 \%$ and a reduction of $5.5 \%$ for strength resistance occurred in G2 and G1, respectively. The possible increase in G2, decrease in G1 and effect of interaction between groups showed distinct behaviors. However, it is not possible to affirm that one intervention was better than the other. A new evaluation after a longer period of time may show statistical results for these differences.

The intervention in health units involved specific exercises of strength resistance using dumbbells, free weights or one's own weight in repetitions and sets with progressive overload, corroborating the findings from similar studies on improvement in such capacity ${ }^{17,20}$. This increase in upper limb strength resistance can be partly explained by the greater number and use of motor units and muscle fibers, thus increasing strength resistance through training principles, especially specificity ${ }^{18}$.

The present study had some limitations, such as groups not being in the same initial condition; the frequency of classes of both groups not being controlled; and the analysis not being performed by sex due to the low number of men. However, the results of the present study show that, regardless of this, physical exercise interventions maintain and improve some physical fitness capacities of elderly individuals, an important factor to alleviate the harmful effects of the aging process.

Adapted Volleyball and PEFUS interventions can provide significant benefits to participants' motor coordination. Considering the fact that the aging process itself overloads the organism, these interventions are important to maintain and improve elderly individuals' physical fitness. Longitudinal studies and evaluations are required to assess the continuation and development of improvements in fitness aspects, especially strength resistance, which showed a trend towards different results between groups.

\section{Acknowledgements}

Authors would like to thank PIBIC/CNPq for the Undergraduate Research Project grant, the members of the Núcleo de Atividade Física Esporte e Saúde (NAFES Health, Sports and Physical Activity Center), the elderly participants in the study and research project, and the Physical Education professional of the city's adapted volleyball team.

\section{References}

1. OMS. Organização Mundial de Saúde. Fatores interessantes sobre o envelhecimento. Disponível em: http://www.who.int/ageing/about/facts/en/index.html.

2. IBGE, 2010. Diminui a proporção de jovens e aumenta a de idosos. Disponível em: http:// www.ibge.gov.br/home/presidencia/noticias/noticia_visualiza.php?id_noticia=1866\&id_ pagina $=1$. 
3. Nóbrega ACL, Freitas EV, Oliveira MAB, Leitão MB, Lazzoli JK, Nahas, RM, et al. Posicionamento oficial da sociedade brasileira de medicina do esporte e da sociedade brasileira de geriatria e gerontologia: Atividade física e saúde do idoso. Rev Bras Med Esporte. 1999; 5(6): 207-11.

4. Hollman W, Hettinger T. Medicina do esporte: fundamentos anatômicos - fisiológicos para prática esportiva. 4 ed. Barueri, SP: Manole, 2005.

5. Pauli, JR, Souza LS, Zago AS, Gobbi S. Influência de 12 anos de prática de atividade física regular em programa supervisionado para idosos. Rev Bras Cineantropom Desempenho Hum. 2009;11(3): 255-60.

6. Mcardle W, Katch FI, Katch VL. Fisiologia do Exercício - Nutrição, energia e desempenho humano. 7 ed. Rio de Janeiro, RJ: Editora Guanabara, 2011.

7. Matsudo SM. Envelhecimento, atividade física e saúde. Bol InstSaúde. 2009; 47:76-9.

8. Benedetti TRB, Gonçalves LHT, Mota JAPS. Uma proposta de política pública de atividade física para idosos. Contexto Enferm. 2007; 16(3): 387-98.

9. Hallal PC, Andersen LB, Bull FC, Guthold R, Haskell W, Ekelund U, et al. Global physical activity levels: surveillance progress, pitfalls, and prospects. Lancet. 2012; 380: 247-57.

10. Laurindo MA, Nadal CS, Vieira D, Aplewicz JGF, Ecave C, Junior GBV. Aptidão funcional em idosas: um estudo de caso da equipe de vôlei UATI. Revista CPAQV. 2009;

11. Oliveira IV. Voleibol adaptado para melhor idade. Disponível em: http://www. conexaoitajuba.com.br/itajuba/Pagina.do;jsessionid=i0447 rnfghmk?idSecao=191\&id Noticia $=11000$.

12. Zorzetto, LP. Comparação entre modelos de intervenção de exercício físico em unidade de saúde e suas influências na aderência e variáveis relacionadas à saúde [dissertação de mestrado]. Rio Claro: Universidade Estadual Paulista; 2013.

13. Kokubun E, Luciano E, Sibuya CY, Queiroga MR, Ribeiro PAB, Silveira RF, et al. Programa de atividade física em unidades básicas de saúde: relato de experiência no município de Rio Claro-SP. Rev Bras Ativ Fís Saúde. 2007; 12(1): 45-53.

14. Nakamura PM, Papini CB, Chiyoda A, Gomes GAO, Netto AV, Pignatti IT, et al. Programa de intervenção para a prática de atividade física: Saúde Ativa Rio Claro. Rev bras Ativ Fís Saúde. 2010; 15(2): 128-32.

15. Osness WH. Functional Fitness Assessment for adults over 60 years. The American Alliance for Health, Physical Education, Recreation and Dance, 1990.

16. Cipriani NCS, Meurer ST, Benedetti TRB, Lopes MA. Aptidão funcional de idosas praticantes de atividades físicas. Rev Bras Cineantropom Desempenho Hum. 2010; 12(2): 106-11.

17. Ueno DT, Gobbi S, Teixeira CVL, Sebastião E, Prado AKG, Costa JLR, et al. Efeito de três modalidades de atividade física na capacidade funcional de idosos. Rev Bras Educ Fís Esporte. 2012; 26(2): 273-81.

18. Gobbi S, Villar R, Zago AS. Bases teórico-práticas do condicionamento físico. Rio de Janeiro: Editora Guanabara Koogan S.A., 2005.

19. Hoefelmann CP, Benedeti TRB, Antes DL, Lopes MA, Mazo GZ, Korn S. Aptidão funcional de mulheres idosas ativas com 80 anos ou mais. Motriz. 2011; 17(1): 19-25.

20. Moraes WM, Souza PRM, Pinheiro MHN, Irigoyen MC, Medeiros A, Koike MK. Programa de exercícios físicos baseado em frequência semanal mínima: efeitos na pressão arterial e aptidão física em idosos hipertensos. Rev Bras Fisioter, 2011.

CORRESPONDING

AUTHOR

LEONARDO DE CAMPOS

leocampos_89@hotmail.con
Avenida 57, número 1381

Jardim Kennesy, Rio Claro, SP, Brasil

13501-550

Telephone: 5519 98423-9020
RECEIVED

REVIEWED $\quad 01 / 12 / 2015$

ACCEPTED $\quad 21 / 12 / 2015$ 